\title{
An Empirical Analysis of Capital Structure on Performance of Firms in the Petroleum Industry in Nigeria
}

\author{
Oladeji, Tolulope, Ikpefan, A.O and Olokoyo, F.O \\ Department of Banking and Finance, Covenant University, Ota, Ogun State \\ Correspondence should be addressed to: Oladeji, Tolulope, Ikpefan; \\ tolulope.oladeji@covenantuniversity.edu.ng
}

Received date: 20 February 2015; Accepted date: 14 August 2015; Published date: 8 December 2015

Accademic Editor: Dana-Maria Boldeanu

Copyright (C 2015. Oladeji, Tolulope, Ikpefan, A. O and Olokoyo, F. O. Distributed under Creative Commons CC-BY 4.0

\begin{abstract}
The capital structure decision of a firm is very paramount to its successful operation. The objective of the study was to analyse the impact of capital structure on firm performance in Nigeria from 2003 to 2012. Using data from six petroleum companies in Nigeria namely: Chevron Plc, Conoil Plc, Eterna Oil plc, Mobil Oil Plc, Oando Plc and Total Nigeria Plc. The study carried out a panel data analysis by using fixed effect estimation. The study found that a negative relationship exists between leverage and firm performance and the study established that a positive a relationship exists between three of the explanatory variables (firm's size, tax and lagged return of asset) and firm performance. The study therefore recommended that the management of the industry should rely more on equity financing as a way of funding their business.
\end{abstract}

Key words: Capital Structure, Firm performance, Leverage, Firm's size.

\section{Introduction}

The objectives of firms revolve round ensuring that they satisfy all the stakeholders involved in the business. The manager of a firm has to make both financing and investment decisions that will aid the realisation of the firm's objective. In making financing decision, one of the priorities of the manager is to ensure that he selects the best financing mix or capital structure of the firm (Ogebe et al, 2013). Capital structure can be viewed as a way in which a firm can finance its whole operations and growth through the utilisation of various sources of funds. The capacity of companies to carry out the needs of their stakeholders is closely associated with capital structure (San and Heng, 2011).

The determination of the capital structure of a firm is challenging in reality. In deciding the optimal capital structure, a firm might have to issue various securities in a limitless mixture in order to have a combination that will maximize its overall value (San and Heng, 2011). There is a close relationship between capital structure and corporate performance (Tian and Zeitun, 2007).The measurement of a firm's performance can be done through the utilisation of variables which involve productivity, profitability, growth or 
customer's satisfaction. These measures have some sort of connections between them.

Financial measurement has been found to be one of the tools which reveal the financial strengths, weaknesses, opportunities and threats. As stated by Barbosa and Louri (2005), the financial measurements are return on investment (ROI), residual income (RI), earning per share (EPS), return on Asset (ROA), dividend yield, price earning yield, price earnings ratio, growth in sales, market capitalization etc.

\section{Statement of the Problem}

A lot of research has been done on this subject in the past but most have focussed more on developed economies, and sparse literature is available from the developing countries especially the oil producing economies. More so, the impact of capital structure on corporate performance in Nigeria has been a bone of contention amongst researchers. Muritala (2012) carried out a similar research but the focus was on the manufacturing sector of the Nigerian economy. Muritala (2012) was in support of more of equity financing as against debt financing. The paper utilises current panel data for the analysis of the model. This research will contribute to the body of knowledge by examining the impact of capital structure decisions on firm's performance in the petroleum sector of the Nigerian economy through the use of current data.

Being an oil producing country, with the largest oil companies in the world operating in Nigeria, there is need to look into how these companies make financing decision and how such decision affects the firm's performance. Is there any kind of relationship between their capital structure and performance? This paper is set to address this question. The choice of petroleum companies for this study is hinged on a variety of reasons. First, both companies made the Forbes top 25 companies in Africa for year 2012. Second, they are among the biggest companies listed on the Nigerian Stock Exchanged and have sustained a good track performance over a period of time. Third, they are listed on the floor of the Nigerian Stock Exchange (NSE). Thus, an evacuation of the performance indicators of these companies especially their capital structure as it affects

Following this section, the rest of the paper is organized as follows: section II reviews the literature on the subject; Section III outlines the methodology adopted and model specification; section IV analyses the data collected on the variables of the model; Section V reviews empirical results. And section VI dwells on conclusion and recommendations.

\section{Literature Review}

\section{Theoretical Literature}

The issue of capital structure has been a contentious matter in the literature. The issue of whether to use more debt or less of equity in company's capital structure is not settled. There are certain theories that form the backbone of the capital structure theory. The relevance of capital structure theory to firm performance was first stressed by Modigliani and Miller (1958). The theory states that the decision about company's capital structure is irrelevant to the value of the firm in the absence of bankruptcy costs, asymmetric information, transactions cost, absence of taxes and in an efficient market with homogeneous expectations.

According to the MM theorem, capital structure theories function under perfect market and that the finances of a firm are not related to its value in perfect market. The real world however does not operate on the assumptions pointed out by the MM theorem. This brought about a new research named the static trade-off theory which focussed on the relationship between capital structure theories and firm performance. According to the static tradeoff theory, the choice of a firm concerning the usage of debt finance or equity finance is based on the cost benefits related with each source of funds. The utilisation of debt can have the advantage tax saving and 
bankruptcy cost. Therefore in deciding the optimal capital structure, the company must strike a balance between the cost and benefits linked with each source.

Another group of capital structure theories is the pecking order theory. This theory stated that companies prefer internal financing (income, amortization) and only in a situation when internal cash flow is insufficient for activity financing, they reach for foreign capital (loans, credits). To serve as a last resort, companies launch own external financing, for instance conducting shares issuance. The static trade-off theory is in support of the relevance of the capital structure. The theory advocates that the capital structures of firms are optimal and they move in the direction of the target. The theory also opines that when debt is utilised in capital structure, firms have the challenges of tax benefit and bankruptcy cost. Therefore, this calls for a trade-off amongst the two. The trade-off theory suggests that the firm with high growth potential should reduce borrowing as it is possible to lose value in case of financial distress. Though, the trade-off theory expects that safe firms should have increased debt ratios.

The agency theory is also one of the capital structure theories. It explains the relationship between the principal and the agent in the decision making process concerning the combination of capital structure of the firm. According to Jensen and Meckling (1976), the agency problem between principal and agent is multifaceted and it plays a crucial role in making decision about the optimal capital structure in a firm.

The traditional theory of capital structure believes that debt capital is inexpensive compared to equity; therefore such a company can raise its value via borrowing up to a realistic level. The theory is based on the assumption that the cost of debt stays the same until a significant level is attained when it would start to increase; the weighted average cost of capital (WACC) will fall as soon as an external source of finance is introduced and it will start to rise thereafter as the level of gearing rises; the company's market value and the market value per share will be maximised where WACC is the lowest point.

The traditional theory advanced that an optimal capital structure exists which maximises the value of the firm and reduces the cost of capital. The theory affirms that the value of the firm cannot be the same at varying levels of capital structure. It should be noted that in spite of all the theories reviewed above, authors like Brav et al (2005) and Graham and Harvey (2001) found that these theories and their assumptions do not have a significant correlation to the determination of capital structure decisions in the firms. More so, the relevance of these theories to the actual capital structure decisions in firms has reduced.

\section{Empirical Literature}

Abbadi and Abu-Rub (2012) examined the effect of capital structure on the performance of Palestinian financial institutions. Using the multiple linear regression models, they utilised the data of 8 banks listed on the Palestine Securities Exchange. They found that a positive relationship exists between leverage and market efficiency. In a related research, Ali et al (2012) analysed the impact of capital structure on the profitability of petroleum sector of Pakistan while controlling the size of the company. They carried out a regression analysis on the data of 12 randomly selected companies for a period of 10years. They found that in overall analysis, there is a significant and positive impact of capital structure on the profitability of the petroleum sector whereas in individual analysis the analysis has no significance because every company has their own capital structure.

David and Olorunfemi (2010) used panel data analysis to analyse capital structure and corporate performance in Nigeria petroleum industry. They found that a positive relationship exist between earning per share and leverage ratio on one hand and positive relationship between dividend per share and leverage ratio on the other hand. 
However, in a similar study carried out by Khan (2012) on 36 engineering sector firms in Pakistan, he was able to establish that financial leverage has an insignificant negative relationship with firm performance. He noted that firms in the engineering sector of Pakistan are mainly dependent on short term debt. In another research, Ogebe et al (2013) investigated the impact of capital structure on firm performance in Nigeria for a period of 10years.They used the fixed effect regression estimation model to confirm that a negative relationship exists between performance and leverage of the firms. They also affirmed that the traditional capital structure theory is valid.

Salawu (2007) carried out an empirical analysis of the capital structure of selected quoted companies in Nigeria between 1990 and 2004.Using panel data analysis; the author found that leverage is negatively related to profitability. He also confirmed tangibility is positively associated with total debts and long term debt though negative related to short term debt. He also opined that collateral has influence on all bank borrowing in Nigeria whether short term or long term. Furthermore, growth opportunity was found to be positively related to both total debts and short term debts.

Olokoyo (2013) examined the impact of leverage on firm's performance in Nigeria using fixed-effect estimation, random-effect estimation and a pooled regression model. The author found that all the leverage measures have a positive and highly significant relationship with the market performance measure (Tobin's Q). The study further revealed an important fact that Nigerian firms are either majorly financed by equity capital or a mix of equity capital or short-term financing. The study recommended that Nigerian firms should endeavour to match their high market performance with real activities that is potent enough to make the market performance reflect on their internal growth and accounting performance.

Following the review of empirical studies the optimal capital structure of a firm is very paramount to its successful operation though these decisions differ from one firm to another. Some authors are of the view that a positive relationship exists between capital structure and the firm performance while some believes that there is a negative relationship. The need to carry out a study that focuses on the petroleum companies in Nigeria is fuelled by dearth of literature on this area.

\section{Methodology}

\section{Model Specification}

In a bid to capture the impact of capital structure on firm's performance, a model in line with the traditional theory of capital structure is specified. For the purpose of this study, we adopt the capital structure model that states that the performance of the firm depends on the capital structure and some control variables. Thus, following Ogebe et al, 2013, the model adopted in this study is stated in its functional form as:

$$
\begin{aligned}
& \text { Performance }=f \text { (leverage, size, tax }) \\
& \mathrm{ROA}_{\text {it }}=\beta_{0}+\beta_{1} \mathrm{LEV}_{\text {it }}+\beta_{2} \mathrm{SIZE}_{\mathrm{it}}+\beta_{3} \mathrm{TAX}_{\mathrm{it}}+ \\
& \beta_{4} \mathrm{ROA}_{\mathrm{t}-1}+\mathrm{Yt}+\varepsilon_{\mathrm{t}}
\end{aligned}
$$

The above model shows that the firm's performance relies on capital structure, size of the firm, tax and lagged returns on asset

Where: ROA = Return on asset

LEV = Leverage (captures the gearing level of firms)

Size $=$ Firm size or size of the firm

TAX = Tax measured as total corporate tax to earnings before interest and tax

$$
\begin{aligned}
& \mathrm{ROA}_{\mathrm{t}-1} \text { = Lagged return on asset } \\
& \mathrm{Yt}=\text { Year effect } \\
& \varepsilon_{\mathrm{t}}=\text { the error term }
\end{aligned}
$$

\section{A Priori Expectation}

Theoretically, there is an expectation of a significant positive relationship between 
the leverage and firm performance; a significant positive relationship between size and firm performance and between tax and firm performance and also between the lagged return on asset and firm performance.

$$
\text { i.e } \beta_{1}>0, \beta_{2}>0, \beta_{3}>0, \beta_{4}>0
$$

\section{Hypothesis of the Study}

The following hypothesis was formulated and stated in their null form and will be tested for the purpose of this study:

\section{Hypothesis 1}

$\mathrm{H}_{1}$ : Leverage has no significant impact on firm's performance

\section{Hypothesis 2}

$\mathrm{H}_{2}$ : There is no significant effect of firm's size on firm's performance.

\section{Hypothesis 3}

$\mathrm{H}_{3}$ : There is no significant relationship between tax and firm's performance.

\section{Hypothesis 4}

H4: There is no significant effect of lagged returns on asset on firm's performance.

\section{Sources of Data and Definition of Variables}

This study utilised secondary data. The data were sourced mainly from the annual report of 6 selected petroleum companies in Nigeria for the period 2003-2012.The Factbook which is a publication of the Nigerian Stock Exchange was also used in sourcing for data. The Petroleum companies are: Chevron Plc, Conoil Plc, Eterna Oil plc, Mobil Oil Plc, Oando Plc and Total Nigeria Plc. The choice of petroleum companies for this study is hinged on a variety of reasons. Besides being amongst the top petroleum companies in Africa for the year 2012; they are amongst the biggest companies listed on the Nigerian Stock Exchange and have sustained a good track performance over a period of time.

\section{Definition of Variables}

In the study, the following variables were used.

- Return on asset (ROA) is measured by earnings before interest and tax (EBIT) divided by total assets. Return of asset was used to measure the firm performance.

- Leverage: it refers to the use of fixed charges source of funds such as debt, bond and debenture capital plus the owners' equity in the capital structure. It is used to express the capital structure which is measured by total liabilities or total debt to total asset (TDTA),

- Firm size: it is the control variable measured by logarithm of the firm's turnover (SIZE)

- $\quad \boldsymbol{T a x}$ (TAX): corporate income tax is a tax based on the income by a corporation. It is measured as the total corporate tax to earnings before interest and tax

- $\quad$ Year effect (Y): the year effect was introduced into the model to control for the difference. It will help to check for annual difference that will affect the return on asset. It will serve as an explanatory variable to show that all other factors that could affect the firm's performance have been considered. It will also help to show that the model is correctly specified.

\section{Method of Estimation}

The data utilised for this study are presented in ratios. We consider pooled as well as fixed effect model estimation technique. Since the number of cross sectional unit is lesser than the parameters in the equation above, random effect estimate is not suitable. In addition, in order to address the heterogeneity bias of 
pooled regression, the fixed effect was also carried out. There were 60 observations that cut across the six selected petroleum companies in Nigeria to cover a period of $10 y e a r s$ with one dependent variable(ROA) and four independent variables (TDTA,
SIZE,TAX, ROA(-1) ). The Gretl statistical package was used to analyse the model.

\section{Results and Discussion}

The results of the pooled and fixed effect regression were run and compared. Find below the result of the analysis carried out.

Table 1: Panel Regression results (Dependent -ROA)

\begin{tabular}{|l|l|l|l|l|}
\hline \multicolumn{1}{|c|}{ Variables } & \multicolumn{2}{c|}{ Pooled OLS } & \multicolumn{2}{c|}{ Fixed Effect } \\
\hline & Coefficient & Pvalue & Coefficient & Pvalue \\
\hline Constant & 25.2964 & $0.06508^{*}$ & 35.3497 & $0.00784^{* * *}$ \\
\hline TDTA & -0.11003 & 0.11105 & -0.255503 & $0.00061^{* * *}$ \\
\hline SIZE & -0.0330818 & 0.32342 & 0.0849819 & 0.16022 \\
\hline TAX & 0.262542 & $0.03662^{* *}$ & 0.288292 & $0.02022^{* *}$ \\
\hline Y & -0.0124325 & $0.06993^{*}$ & -0.0178341 & $0.00796^{* * *}$ \\
\hline ROA_1 & 0.455346 & $<0.00001^{* * *}$ & 0.179095 & $0.05863^{*}$ \\
\hline $\mathrm{R}^{2}$ & 0.704978 & & 0.799321 & \\
\hline Adjusted R ${ }^{2}$ & 0.674246 & & 0.752652 & \\
\hline Durbin Watson & 2.397889 & & 2.070495 & \\
\hline Note: *, ** and ${ }^{* * *}$ signifies 10\%, 5\% and 1\% level of significance respectively \\
\hline $\begin{array}{l}\text { Source: Authors' computation } \\
\text { (Obtained from the data analysis using the GRETL statistical software package) }\end{array}$
\end{tabular}

The above table presents the estimated result for the six oil companies in Nigeria (Chevron Plc, Conoil Plc, Eterna Oil plc, Mobil Oil Plc, Oando Plc and Total Nigeria Plc) for the period 2003 - 2012. After the estimation, the fixed effect model was found to reflect a more robust estimate compared to the pooled regression; therefore the fixed effect was adopted in our analysis.

Fitting the values into the estimated model, we have:

Model: ROA $=35.3497-0.255503 \mathrm{LEV}_{\text {it }}+0.0849819$ SIZE $_{\text {it }}+0.288292 \mathrm{TAX}_{\text {it }}+0.179095 \mathrm{ROA}_{\mathrm{t}-1}$ - 0.0178341Yit

$$
\text { S.E } \quad(0.0677765) \quad(0.0331577)
$$

From the table above, it can be observed that three of the independent variables are positively correlated as expected theoretically and also confirmed empirically by authors like Tian \& Zeitun (2007) and Gleason et al. (2000) except for the leverage ratio (TDTA) that had a negative correlation which also confirms theoretical expectation. The negative relationship between leverage and firm performance is confirmed by authors like Khan (2012), Onaolapo and Kajola (2010), Abor 2007 and Deesomak et al (2004).The

$$
(0.122111)
$$

coefficient of determination $\left(\mathrm{R}^{2)}\right.$ shows that approximately $80 \%$ of the systemic variation in the ROA was explained by the TDTA, SIZE, TAX and ROA $(-1)$. The result obtained from the model revealed that the overall coefficient of determination $\left(\mathrm{R}^{2}\right)$ shows that the equation has a good fit with $80 \%$ change in ROA caused by the independent variables. The higher the $\mathrm{R}^{2}$ the higher the goodness of fit, and the higher the reliability of the model will be. 
The Adjusted $\mathrm{R}^{2}$ has the tendency to eliminate the influence of the number of included explanatory variables. The adjusted $\mathrm{R}^{2}$ value of approximately $75 \%$ suggests that the model's is still of good fit. The Durbin Watson (DW) statistic value of 2.07 implies the absence of autocorrelation as it is significantly within the benchmark. The low DW also implies that the estimated equation can be relied upon in making valid inference about the influence of the explanatory variable on the market performance of Nigerian Petroleum companies. This also confirms that the right combinations of explanatory variables were used.

The analysis confirmed that TDTA was statistically significant at $1 \%$ while tax was statistically significant at 5\%, the lagged return on asset $(\operatorname{ROA}(-1))$ was significant at $10 \%$ however size was found not to be significant though it has positive impact on firm performance. Finally, the year effect that was introduced to check for the annual difference that could affect return on asset was also significant at $1 \%$. This further confirms that model used in this study was correctly specified.

\section{Findings and Recommendation}

The study empirically analysed the effect of capital structure on firm performance in the Nigerian Petroleum Industry using panel data analysis of 6 petroleum companies in Nigeria between 2003 and 2012. The study confirms the validity of the traditional theory of capital structure.

Contrary to the traditional theory which posits that a positive relationship exists between leverage and firm's performance, this study found that a negative relationship exists between leverage and firm performance. In the last two months (Jan-feb 2014) the media and Nigeria Senate Committee on Petroleum Matters has been awash with logged jam between the Central Bank of Nigeria and the Nigerian National Petroleum Company over missing 10 billion naira irreconcilable account that is yet to be paid into the account of Central Bank of Nigeria by Nigeria National Petroleum Company. This type of financial behaviour, irresponsibility and situation is bound to defy the traditional theory. Thus in a company where there is no judicious use of funds (e.g Petroleum company), borrowed funds might not have positive impact on performance due to fraud, corruption, wastage or misappropriation etc.

The inference that can be drawn from this is that leverage has a negative effect on the performance of a firm. The result of this study is also in line with various empirical studies. This study also found that a positive relationship exists between the firm's size and firm performance as well as between tax and firm performance; the lagged return on asset also had a positive relationship with firm performance. The implication is that the size, tax and the lagged return on asset can be considered to have a positive influence on the performance of a firm. Since leverage has a negative effect on the firm's performance, it is therefore recommended for the petroleum industry to rely more on equity financing as a way of raising funds for their business. They should reduce their borrowing operations which could make them go bankrupt.

However, this study brings to the fore recent happening in the Nigerian Petroleum Sector. Between (Jan-February, 2014) the media and Nigerian Senate Committee on Petroleum Matters have been awash with logged jam between the Central Bank of Nigeria and the Nigerian National Petroleum Company over missing (ten)10 billion naira irreconcilable account that is yet to be paid into the account of Central Bank of Nigeria by the Nigerian National Petroleum Company. This type of financial misbehaviour, irresponsibility and situation is bound to defy the traditional theory. Thus, in a company where there is no judicious use of funds (e.g Petroleum Company), borrowed funds might not have positive impact on performance due to fraud, corruption, wastage or misappropriation etc. In the Manufacturing sector specifically the Nigerian brewery where funds have been used judiciously results showed that performance was enhanced. Ikpefan and Enahoro (2007) used time series (ordinary least square method) to analyse sales, operating 
leverage, financial leverage and combined leverage in the Nigerian brewery industry between (1979-2004). The result showed that sales, operating leverage, financial leverage and combined leverage have significant influence on earnings of Nigerian Brewery Plc. In contrast, the result of this study clearly shows that despite the huge capital available at the disposal of the management of the Nigerian petroleum sector, the human capital (personnel) have not used the petroleum resources to the benefit of the citizens. Nigeria being a mono economy relying solely on oil has suffered over the years as a corporate entity and at the individual level as a result of misuse of God given resources. Nigeria as a nation has suffered from the lack of infrastructures, epileptic power supply, dilapidated schools, unemployment etc because of misappropriation of funds.

This study strongly recommends the passing into law of the 2013 Petroleum Industry Bill (PIB) by the Nigerian National Assembly in order to refocus petroleum sector to greater height. The petroleum Industry Bill (PIB) addresses issues like withdrawal of subsidy, autonomy of the sector from government funding (i.e selfsustaining) etc. This study is limited to only six leading oil companies in Nigeria. Future researchers should extend the sample size to cover more oil companies in the petroleum sector to revalidate the findings of this research.

\section{References}

1. Abbadi, S and Abu-Rub, N (2012): "The Effect of Capital structure on the Performance of Palestinian Financial Institutions" British Journal of Economics, Finance and Management Sciences. Vol.3, No 2, $P$ p 92-101

2. Abor, J. (2007): "Debt policy and performance of SMEs: evidence from Ghanaian and South Africa firms", Journal of Risk Finance, Vol. 8, pp. 364-79.

3. Ali, S, Zia, S and Razi A(2012): "Impact of Capital Structure on the Profitability of Petroleum sector in Pakistan" Global
Journal of Management and Business Research Volume 12 Issue 22

4. Barbosa, N, and Louri, $\mathrm{H}$. (2005):"Corporate Performance: Does Ownership Matter? A Comparison of Foreign- and Domestic-Owned Firms in Greece and Portugal". Review of Industrial Organization, Vol 27 No.1, Pp73-102.

5. Brav, A., Graham, J., Harvey, C. and Michaely, R. (2005): "Payout policy in the 21st century", Journal of Financial Economics, Vol. 77, pp. 483-527.

6. David,D. and Olorunfemi S(2010): “ Capital Structure and Corporate Performance in Nigeria" Journal of Mathematics and Statistics. Vol. 6 no 2, Pp $168-173$

7. Deesomsak, R., Paudyal, $\mathrm{K}$ and Pescetto, G. (2004): "The determinants of capital structure: evidence from the Asia Pacific region", Journal of Multinational Financial Management, Vol. 14 No. 4/5, pp. 387-405.

8. Gleason, K. Mathur L and Mathur I (2000): "The Interrelationship between Culture, Capital Structure and Performance: Evidence from Europeans Retailers", Journal of Business Research, Vol. 50, pp. $185-191$.

9. Graham, J. and Harvey, C. (2001): "The theory and practice of corporate finance: evidence from the field", Journal of Financial Economics, Vol. 60, pp. 187-243.

10. Ikpefan, O.A and Enahoro, J.A (2007): "Interface of Leverage and Earnings: An Investigation into the Nigerian Manufacturing Sector", The Nigerian Accountant, October/December, Vol.40, No.4

11. Jensen, $M$ and Meckling, W. (1976): "Theory of the firm: Managerial Behavior, agency costs and ownership structure", Journal of Financial Economics, Vol. 3, pp. 305-60.

12. Khan, A (2012): "The relationship of capital structure decisions with firm performance: a study of the engineering 
sector of Pakistan". International Journal of Accounting and Financial Reporting. Vol 2,No 1 Pp245 - 262

13. Michalak, A(2013): "Theoretical conceptions of optimal capital structure" Management Knowledge and learning international conference 19-21 June 2013

14. Modigliani, F. and Miller, M. (1958): "The cost of capital, corporate finance and the theory of investment", American Economic Review, Vol. 48, pp. 261-297.

15. Muritala, T (2012): "An Empirical Analysis of Capital Structure on Firms' Performance in Nigeria" International Journal of Advances in Management and Economics. Vol.1, Issue 5, Pp 116- 124

16. Ogebe, O, Ogebe J and Alewi K(2013): "The Impact of capital structure on firm's performance in Nigeria". MPRA Paper No. 46173

17. Olokoyo, F. O. (2013): “Capital Structure and Corporate Performance of Nigerian Quoted Firms: A Panel Data Approach" African Development Review.
Volume 25, Issue 3, pages 358-369, September 2013

18. Onaolapo, A. A. and Kajola, S. O. (2010): "Capital Structure and Firm Performance: Evidence from Nigeria", European Journal of Economics, Finance and Administrative Sciences, Issue, 25, pp.70-82.

19. Salawu R (2007): “An Empirical Analysis of the Capital Structure of Selected Quoted Companies in Nigeria. The International Journal of Applied Economics and Finance. Pp 16 -18.

20. San, 0 and Heng T( 2011): "Capital Structure and Corporate Performance of Malaysian Construction Sector" International Journal of Humanities and Social Science. Vol.1 No2. Pp28-36

21. Tian, G. G. and R. Zeitun (2007): "Capital Structure and Corporate Performance: Evidence from Jordan" Australasian Accounting Business \& Finance Journal, Vol. 1, Issue 4, pp. 40 - 61. 